\title{
National and Higher Education Institutions (HEls) IP Policies: Comparison of Indian HEls' IP Policies from a Global Perspective
}

\author{
Vijay Sattiraju ${ }^{1} \cdot$ Virendra S. Ligade $^{1} \cdot$ Pradeep Muragundi $^{1} \cdot$ Ravi Pandey $^{2}$. \\ Manthan D. Janodia ${ }^{1}$ (D)
}

Received: 19 January 2021 / Accepted: 13 January 2022

(c) The Author(s) 2022

\begin{abstract}
Until the end of the eighteenth century, Higher Education Institutions (HEIs) were restricted to generate knowledge for free access to industries which they use for making commercial products. Though HEIs have the potential to contribute to the national economy from their creative and commercially viable R\&D output through commercialization of research and Intellectual Property Rights, it was not given the needed importance due to lack of supportive policies. In many developed countries, innovation strategies, Science, Technology, and Innovation (STI) and national Intellectual Property Rights (IPR) policies provided opportunities to HEIs to own and commercialize knowledge they generate. National IPR policy and formulation and implementation of HEI IP policies became crucial for effective implementation, promotion of innovation, generation, and protection of IP in the HEIs. Efficiency of HEI in commercializing research is dependent on national IP policy framework aligning vision and goals of HEI IP policy with national IP policy, objectives, ownership, and revenue sharing mechanism. These are the key indicators for comparing the institutions' innovation and IP capacity. This paper uses these indicators to discuss the impact of different countries' (developed, developing, and least developed) national IPR policy frameworks on top-performing HEIs of those countries and to address the research question, how national and HEI IP policies have worked in achieving envisaged economic growth by improving innovation output of the HEIs. It further compares Indian HEI IP policies with global HEIs. We found that there is a greater need for local governments and HEIs to make their incentive strategies and policies in line with their corresponding national frameworks for facilitating the collaboration and commercialization of innovations. Implementing a robust IP policy framework at state/region and HEI level plays a pivotal role in creating an innovation ecosystem supportive to envisaged national economic growth.
\end{abstract}

Keywords Intellectual property policy $\cdot$ Innovation $\cdot$ Higher education institution

Extended author information available on the last page of the article 


\section{Introduction}

Until the end of the eighteenth century, Higher Education Institutions (HEIs) were restricted to generate knowledge for free access to industries, which were used by industries for commercial gains. Though HEIs have the potential to contribute to the national economy from their innovative and commercially viable research and development, it was not given much importance due to lack of a supportive policy framework. The increased interest on commercialization of university generated research paved the way for development of policies to support such activities (Rasmussen et al., 2006). Though industries are the main source of research, development, and innovation, HEIs are the main source of knowledge creation and dissemination for these industries (Cantù et al., 2015). In the developed countries like the USA, firms contribute to research and development activities, while in developing countries like India, public funded research in HEIs is the main source of knowledge generation (Ghosh et al., 2016; Kashyap \& Agrawal, 2019). Christopher Freeman in 1987 identified that industry linkage is an important factor for the economic performance of nations while studying the post-war Japanese technology development. He identified that the linkages among enterprises, government agencies, and universities influence the country's innovation. He termed it as the Japanese system of innovation. Later, the concept of National Innovation System (NIS) was developed by him and the same idea was used for studying industrialization in Denmark by various economists (Lundvall, 2007). These studies from Japan and Denmark explain the relationship among universities, government research institutions, and their linkages with private enterprises and their effect on economic development. The flow of knowledge and information among these actors results in generation and promotion of innovation and technology development (Du Plessis, 2007; Lundvall \& Borrás, 2005).

Understanding these linkages among universities and research institutes, enterprises and human capital is the main concept involved in NIS (Godin, 2009; Lundvall, 2007) and the same helps in improving the economic performance of a country. The role of institutions and organizations and their linkages differ among countries' systems of innovation. For example, universities emphasize on research in the USA and Western Europe, whereas in Japan, firms and private research institutes play a major role (Nakayama \& Low, 1997). The term "institution" includes not only organizations, research institutions, and universities, but also policies, legislation, economic activities, and processes involved in shaping them (Edquist, 1997) The frameworks of these processes in institutions make the institutional system.

The interaction between technological and institutional systems, innovation policy framework, and design of policy instruments significantly affect the development of the NIS (Foxon et al., 2004). The Intellectual Property system plays a key role in NIS by providing a legal protection to the knowledge and technology flow from lab to market. It promotes innovation and encourages innovators by providing temporary monopoly as an incentive to their intellectual output. 
Balancing the societal needs and promoting innovation is often challenging for governments. It needs an IPR policy at the national level along with a legislation harmonizing with international conventions, addressing the issues of the nation in promoting the self-sufficiency in $\mathrm{R} \& \mathrm{D}$, along with meeting the societal benefits. This IPR policy should be part of national development goals and economic growth programs to attain maximum benefit out of it through HEIs. It is quintessential for mode 3 universities (Carayannis et al., 2018). ${ }^{1}$ Understanding these differences between formulation and implementation of institutional policy and national policy framework among developed, developing, and least developed countries helps in understanding the impact of national IP policy in different NIS on HEIs. The efficiency of HEIs is dependent on the following variables: (a) its mission and objective of the national IP policy framework and implementation, (b) vision and goals of HEI IP policy, (c) objectives, (d) ownership, and (e) revenue sharing mechanism. We used these indicators for comparing national and institutions' IP policy formulation to discuss variation in policy framework with respect to level of economic development (in developed, developing, and least developed countries) and its impact on top-performing HEIs and how it worked in achieving envisaged economic growth through innovation output of the HEIs. It further compares Indian HEI IP policies from a global perspective.

The framework of this paper proceeds as follows. "Methodology" details the methodology used to study national and HEI IP policies, "IPR Policy Among Other Related Policy Areas" discusses the role of IPR policy among other STI policies, "Policy Framework Variations in Different Countries" describes differences in IP policy among different countries (developed, developing, and least developed countries) and compares IP policies of HEIs in these countries, "HEIs' (Universities and Research Laboratories) IPR Policies in Different Countries" talks about the impact of national IP policies on IP generation by HEIs, and "Impact of National IPR Policies and HEIs' (Universities and Research laboratories) IP Policies on IP Generation" compares IP policy of India and the USA. Finally, the paper summarizes the steps required to improve IP in HEIs in India.

\section{Methodology}

The primary objective of this study was to answer the research question, 'How national and HEI IP policies varies among developed, developing, and least developed countries and how it impacts innovation in HEIs'. To fulfil this objective, empirical analysis was carried out using national IPR policy/strategy documents released by respective national governments and research articles were studied. Further, policy documents by industry associations were also taken into consideration for the purpose. The empirical analysis was performed through a comparative approach at two levels: (i) macro (country level) and (ii) micro (HEI level) by taking

\footnotetext{
1 Mode 3 universities encourage high diversity in innovative patterns in teaching, research and innovation and stronger networking with the entrepreneurial ecosystem.
} 
the development status of the country and top HEIs in those countries respectively. The units of comparison and analysis were (i) national IP policies/strategy and (ii) institutional (HEI) IP policy. The countries studied include the USA, Japan, and South Korea among the developed countries, China and South Africa with India among developing countries, and Bangladesh and Nepal among least developed countries (LDCs). The criteria for selecting the specific countries among developed and developing economies are primarily preferred to include 4 of 5 largest Intellectual Property office countries - the USA, China, Japan, and South Korea. Among developing countries, India was studied for comparison with the IP policy of China, and Bangladesh and Nepal were considered for their IP policy being in the Asian region. HEI IP policies of best performing HEIs in global Higher Education Institutions' ranking from developed, developing, and least developed countries are chosen for comparing institutional IP policy framework.

The pictorial description of the methodology is shown in Fig. 1.

\section{IPR Policy Among Other Related Policy Areas}

STI policies are prominent in building the framework of NIS. How these policy areas are unique and different from each other and the position of IP policy among related policy areas are not studied well. However, it is evident from various STI policy studies during 1960-1970 that scopes of these policies are changing as innovation studies are advancing. During the 1960s, science was considered broad and 'Technology' and 'Innovation' were considered part of it (Meyer, 2002). Later, studies in the 1970s identified 'science' as one of the several other components of 'innovation'. Policy aspects of 'science' and 'technology' help in strengthening innovation. The focus of innovation policy is not on specific sectors or technologies, but it concentrates on framework in the system linking these sectors (Lundvall \& Borrás, 2005). It constitutes 'science policy' and 'technology policy' integral to it. Reviewing and redesigning the linkages between the parts of the system is the fundamental to innovation policy.

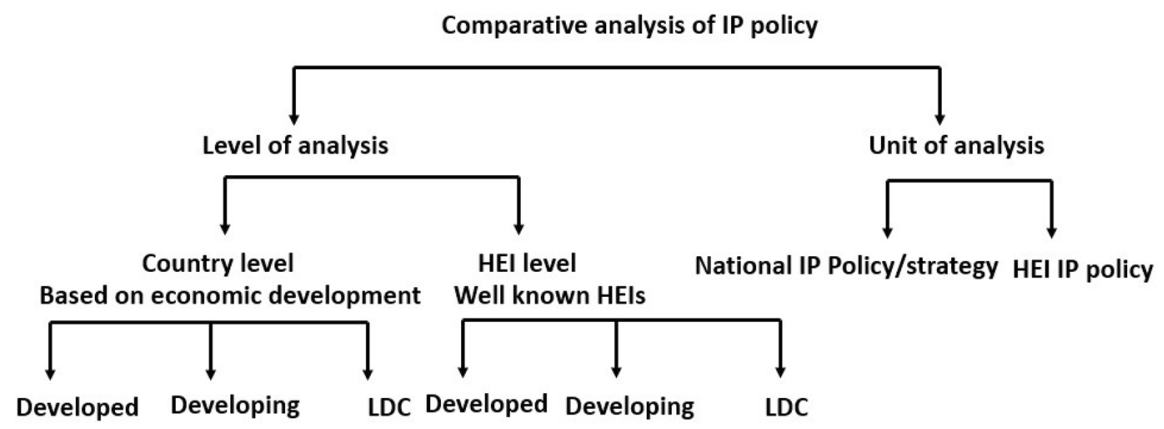

LDC- Least Developed Countries

Fig. 1 Methodology for performing comparative analysis of IP policy 


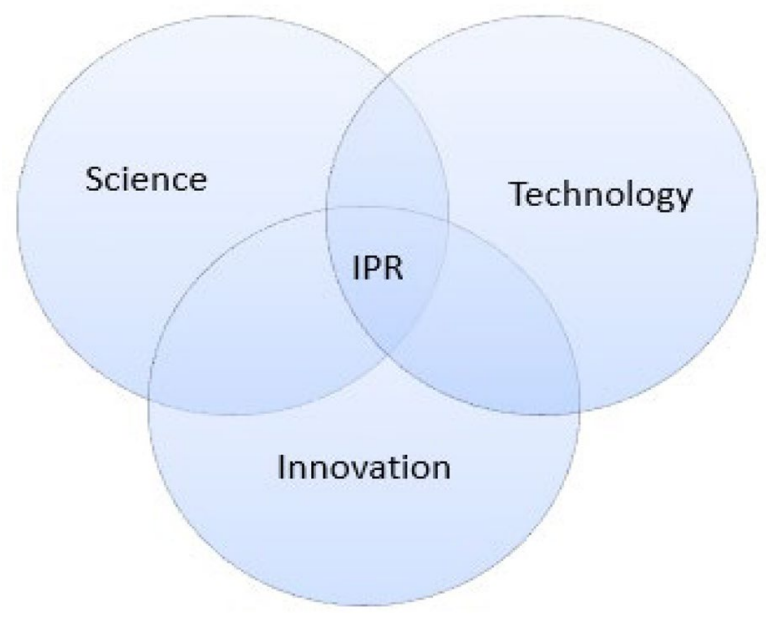

Fig. 2 Intersection of IPR within science, technology, and innovation

IPR policy intersects within the STI frameworks. It deals with the protection of information and knowledge and their flow in science. It helps in the protection of flow of knowledge and technology from lab to market. It provides for dissemination of technology across different jurisdictions, facilitates competitive market for businesses, and creates employment. If IPR policy is used efficiently as a 'policy tool' of innovation policy, it helps in transformation of a country into a R\&D-driven economy. National IPR policy itself works as a tool to achieve the goals of innovation policy of a country and sustainable development goals of the world (Figs. 2 and 3).

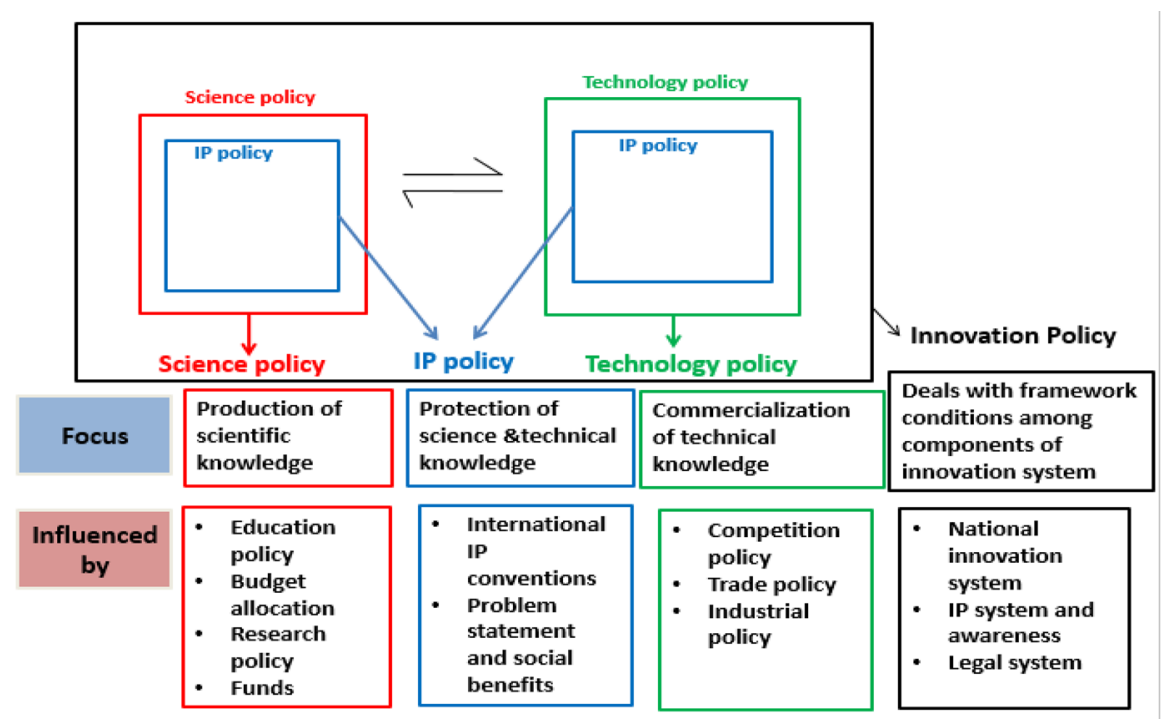

Fig. 3 IP policy within Science, Technology, and Innovation policies. Source: adapted from science, technology and innovation policy, Lundvall et al., The Oxford handbook of innovation, 2005, 599-631 


\section{Intersection of IPR Within Science, Technology and Innovation}

\section{IP Policy Within Science, Technology, and Innovation Policies}

\section{Innovation and IPR Policy}

The key objectives of the innovation policy are to promote 'economic growth' and 'international competitiveness'. Fulfilment of these objectives is indirectly linked to nation's knowledge bases, which are universities and public research institutions considered to be knowledge creators. Strengthening of the IP system to protect the knowledge created and promotion of IP awareness is an important aspect of innovation policy of a country. The science sector, which constitutes universities and research institutes, may not have a direct contribution in national economic growth, but scientific outputs emanated from this sector are providing important inputs to the firm's and nation's innovation activities. STI policies are designed to encourage STI in a country specifically (Payumo et al, 2012; Sampat, 2006). The main difference between 'Science' and 'technology' is that 'science' produces knowledge for public use and encourages published knowledge, while 'technology' produces knowledge that is for private use and often unpublished (Du Plessis, 2007).

Universities and Research Institutes' (RIs) main activities are to educate future human capital and to conduct research in both basic and applied research leading to benefit for the industrial sector. Innovation and technical progress are the outcomes of a complex relationship among actors involved in producing, distributing, and applying various kinds of knowledge. While science policy helps in the promotion of R\&D through knowledge bases, technology policy focuses transfer of knowledge and information for societal benefit and creation of wealth (Gopalakrishnan \& Santoro, 2004). In both policy areas, IP plays a central role. IP policies of HEIs are the prime building blocks of the innovation where it aims for promoting generation and commercialization of IP from knowledge bases. National IPR policies identify strengths and weaknesses of the innovation ecosystem and provide the needed technological framework balancing competition and social benefits. Leveraging both national IPR policy and IP policy of HEIs as a tool of innovation policy enables attaining the goals of innovation.

Protecting and managing the IP of the creator/inventor requires policy guidance at both national and institutional levels for coordinating and promoting research. Strengthening the industry linkage to universities and research institutes and protecting and managing their IP will have a triggering effect on the country's innovation output. Many economists recognized patents as indirect indicators of economic development of the country which also decides the foreign direct investments (FDIs) and international trade (Keller, 2010). Countries like Jamaica, Sri Lanka, Rwanda, Trinidad and Tobago, and Serbia identified the role of IP, and integrated the IP policy with the innovation policy and as a part of the National Development Plan (NDP) (Lundvall \& Borrás, 2005).

Just like public policy, innovation and IP policies are also need reforms with changing times. Policymaking and strategy building are specifically dependent 
on the social, political, and cultural backgrounds of the country (path dependence) (Martin \& Sunley, 2006). While framing these policies, the priorities, issues, and specific needs of a country are needed to be balanced along with norms of international conventions. University-based entrepreneurial developments are thought to be improved by national policies. In some countries like the UK, the commercialization of university generated knowledge is a crucial part of national and regional policies. In the USA, after the implementation of the Bayh-Dole Act (BDA), there was an increase in patenting and commercialization activity in universities. In developing countries, the Intellectual Property Rights (IPR) policy has significant implications for accumulating technological learning and technological capability (Ray \& Bhaduri, 2008).

\section{Policy Framework Variations in Different Countries}

The framework of national IP policies differs mainly on innovation system in a country. It significantly varies between developed, developing, and least developed countries (LDC), and within these economies. Not all the countries have consolidated IP policies yet. In some LDCs, within the sectoral policies they have mentioned their specifications related to IPR. Few countries have released their national IPR strategies consisting of goals and targets, but not as a standalone IPR policy. WIPO has given general guidelines for IP policymaking for countries and for HEIs and encourages all member countries to formulate IP policies. For LDCs, WIPO provides their expertise in setting the IP policy for nations. Sri Lanka, South Africa, and Nepal were among those LDCs to whom WIPO has been involved in setting their IP policies. As per WIPO IP policymaking methodology, there is a need to identify the issues and innovation, and status of the nation, to decide on priorities. Between 2010 and 2018, most of the developing and LDCs formulated their IP policies. The historical evolution of policy and current national IP policies/strategies of developed nations, developing countries, and least developed nations are discussed in this paper. The crucial differences of policy frameworks in these countries are due to the following factors: (a) awareness, IP generation, and commercialization; (b) inter-ministerial co-ordinations; (c) IP administration; and (d) coordination for Enforcement. The study and comparison of national IPR policies of the countries classified under 'Developed, Developing and LDCs' were made under the purview of the abovementioned factors.

\section{Japan}

Comparing to other countries, Japan lacks the natural resources to stand competitive in world economy. It has targeted to use IP as a main source to improve its economic status, but it was opined by many policymakers and analysts that their IP system was outdated and needs to be revived. It aimed to improve the international 
competitiveness of its industrial sector by protecting and using their IP developed from their creative and research activities. As a first step in transforming their country into an IP-based nation, they enacted the 'Basic Act' and established an Intellectual Property Strategy in 2003. It was headed by the Prime Minister and the members as all other sector ministers and constitutes 10 experts ( 4 university professors, 3 CEOs of private firms, an attorney, a patent agent, and a scientist). The IP strategy program was designed which includes 5 chapters and 270 action points. Japan realized universities' role in knowledge creation and Technology Transfer from universities in 1990, whereas USA started it in 1980 through the Bayh-Dole Act. Before the Basic IP Law enactment, Ministry of Education (MEXT) guidelines allowed university researchers to retain rights of IP they generate. In Japan, major research activities are undertaken by national universities and they are not given right as independent legal entities. Private universities in Japan were not bound by the rules of the Ministry of Education. A legislation was enacted in the year 1998 to encourage the Technology Licensing Organizations at universities. In the 1999 Industrial Revitalization Special Law, a Bayh-Dole like Act was enacted. As a part of that, IP centres were established in universities across the country. Functions of universities are expanded from conventional types i.e. Academia and Research along with Technology Transfer as a new function added to it. Universities were encouraged to enhance IP-focused organizations, to set up rules and regulations for IP ownership, and to secure finance for prosecution. Government has chosen 34 universities and provided subsidies to encourage IP-related activities. After this Act implementation, professorial patenting with the industry fell significantly and university-entitled patents were increased. However, these reforms encouraging TLO/TTO mediation in technology commercialization process brought changes in the IP ownership but did not improve the quantity and quality of IP output from universities.

Objectives of the Innovation policy of Japan were concentrated on improving its IP system to support the international competition of their industries. IP policy vision document was framed in 2013, and it has proposed 4 main objectives as pillars. They are as follows: (i) building a global IP system for enhancing industrial competitiveness, (ii) promoting support for IP management of small and medium enterprises and venture companies, (iii) improving the environment for adjusting to the digital network society, and (iv) strengthening the content industry.

\section{India}

Developed countries like the USA attained economic development with implementation of a low protective and highly competitive IP environment, similarly in developing countries attaining economic growth without strong regimes using flexibilities in TRIPS (Reichman, 2009). In most of the developing countries, public consultation on IP issues is underdeveloped. Countries like India, Brazil, and the Philippines have well-developed processes and consultation of experts in IP decision making (Deere Birkbeck, 2009). The policy setting for developing nations is highly challenging as it is often difficult to balance the national 
priorities and satisfy international competition and trade pressure from developed countries. Policies supporting for strong IP protection in developing countries may end up benefiting developed countries with no internal innovation improvements to the nation (Brandl et al., 2019).

\section{National Intellectual Property Rights Policy of India 2016}

A standalone separate IPR policy of India was released in 2016 by the 'Department of Industrial Policy and Promotion' (DIPP), the coordinating department for nurturing Intellectual Property Rights in the country. To draft this policy, it has constituted an IP 'think tank' comprising 6 academicians for preparation of a base document for a National IPR Policy on October 212014 (Basheer \& Agarwal, 2017). The Government has approved the National IPR Policy of India given by DIPP on 12 May 2016, which laid the roadmap for IPR in India. Seven objectives were given in the policy: (i) to create awareness in the public about the socioeconomic and cultural benefits of IPRs among all sections of society, (ii) to stimulate IPR generation, (iii) to enact strong and effective IPR laws balancing public interest and owners' rights, (iv) to strengthen IPR administration, (v) to promote IPRs facilitating commercialization, (vi) to strengthen IPR laws of enforcement and adjudication, and (vii) to strengthen and expand human resources and skill building in IPR.

Though India has a significant knowledge base, due to lack of IP legislation awareness, much of it was not protected. To create public awareness, it has recommended for the introduction of IPR courses in schools and colleges. Specialized IPR institutions were planned for creating skilled professionals. The policy also recommended the setting up of IPR facilitation centres and creating incentives for IPR filings by Micro, Small \& Medium Enterprises (MSME). The model guidelines document was prepared and released by Cell for IPR Promotion \& Management (CIPAM) for the implementation of the IPR policy in academic institutions (Model guidelines on implementation of IPR Policy for academic institutions, 2019). Multiple reforms for enforcement were planned to cull the counterfeit product sale which was reported to be approximately 6 billion USD in the years 2013-2014 as per FICCI (Federation for Indian Chambers of Commerce) report. This policy recommended amendments to the cinematography Act of 1952 to put a criminal liability clause for infringement cases. Legal frameworks for Standard Essential Patents (SEP) and FRAND (Fair, Reasonable, and Non-discriminatory) rules were proposed (Basheer \& Agarwal, 2017). This policy also stressed on traditional knowledge protection by widening the scope of TKDL (National Intellectual IPR Policy, 2016).

\section{Bangladesh}

The Bangladesh IP policy draft was made in the year 2018. It aimed to encourage the country's innovation by using IP as the main tool with a vision of socioeconomic and cultural growth. This policy has the mission of making IP as an integral part of 
the National Development Strategy and declared the period from 2018 to 2028 as the innovation decade. It has specified 6 goals and some strategies to attain the said goals to fulfil the objectives of the proposed IP policy. In strategies of goals 1, 2, and 3 , it has identified the role of academia for stimulating and promoting the country's innovation and given importance for funding of academic research and improving the industry - university linkages. The mechanism of commercializing the public sector research by coordinating innovation; assisting the local scientists on technology transfer and promoting and facilitating the institutional IP policy establishments at universities, R\&D organizations, and public research organizations; developing and strengthening the human resources in the institutions of IP promotion and protection; and introducing IP education in all academic institutions (public and private universities) are other strategies mentioned in the draft policy. It has stipulated a period of 10 years for attaining the goals specified and planned to establish the National Council and Sectoral Committee on intellectual property to follow up and check the implementation of the policy at the national level (National Innovation and Intellectual Property Policy, 2018).

\section{HEls' (Universities and Research Laboratories) IPR Policies in Different Countries}

The aim and objective of HEIs' IP policy is to absorb the objectives stipulated in the national and state/regional IP policy to leverage the maximum benefit out of HEIs' research activities. Ownership, revenue sharing, and system of incentive specified in the policy play a major role in promoting the awareness on IP, and the IP generation and commercialization. In this paper, the 'description and comparison' of HEIs' IP policy of different countries was made on indicators' ownership and revenue sharing mechanism specified in their policies.

The ownership of IP in HEIs can be seen in two models: (i) university ownership and (ii) inventor ownership. Both have advantages and disadvantages. The USA follows the university ownership model where there is a crucial role of TTO/TLO to commercialize the IP generated. Sweden has an inventor ownership model where the inventor has freedom to work on his/her patent for its commercialization.

The revenue sharing mechanism could be linear (fixed) and non-linear (variable) types. In the linear mechanism, there would be a fixed share of revenue distribution among those who contributed in the IP generation, whereas, in the non-linear mechanism, revenue is distributed based on milestone payments after achieving the preset target amount during commercialization/marketing. Most of the European and Australian universities follow this type. This non-linear revenue sharing model can be designed in either (i) a step-up manner (low initial royalty sharing at first pre-set milestones and increases gradually as the milestone amount increase) or (ii) a stepdown manner (high initial royalty at first pre-set milestones and decreases gradually as the milestone amount increases). 


\section{IP Policies of HEIs' in the USA}

\section{Massachusetts Institute of Technology}

The Massachusetts Institute of Technology (MIT) IP policy was last revised in 2018. As per the policy, from the tangible property derived from the single technical disclosure, $15 \%$ shall be deducted as administration fee (expenses of the Technology License Office) and out-of-pocket costs (patent filing, prosecution, maintenance, and marketing costs), and one-third of the share shall be shared to inventor contingent adherence to applicable sponsored research agreement. Coinventor(s) share shall be equal unless otherwise agreed by all in written for variable share. Share of technology licensing office (TLO) and any other departments involved in contribution was mentioned clearly. Each contribution in different cases was termed as case contribution. Share of royalty to departments and centres is decided after deductions of each case cost from gross royalties received i.e. gross royalties minus administrative fee and inventors share minus royalties owed to third parties. They have included the TLO expenses on patent cost within the total net patent expenses and will be reimbursed after payments from licensees were received. The resulting $50 \%$ of revenue shall be shared among departments and centres as per their contribution. The remaining royalties after distribution shall be retained by the MIT general fund. The distribution frequency of the net income was scheduled in the first quarter after the end of the financial year. As per policy, royalties earned by departments, centres, interdisciplinaries, and MIT general fund must be used only for education and research purposes.

\section{Boston College}

The Boston IP policy has primarily two academic aims. First is to share the existing knowledge with students to promote research and scholarly activities in the university. The second is to benefit the individuals who were involved in those scholarly outputs that have commercial activities and university. Regarding ownership of IP, it states that if the inventor is an employee, uses university resources, and is funded by the university, it shall be owned by the university, and if there is no employment responsibility vested with the individual and he/she is not funded by the university, the resources or facilities are owned by the inventor. The revenue share of the inventor after licensing is in non-linear, step-down type, where up to $\$ 5000$ inventor share is $100 \%$, from $\$ 5001$ to $\$ 10,000$ which is $85 \%$ to the inventor and the rest to the provost and dean of the faculty, and from $\$ 10,001$ and above which is $50 \%$ to the inventor and the rest to the provost and dean of the faculty (Edquist, 1997).

\section{Harvard University}

The Harvard University IP policy clarifies the importance of exploiting financially, and it specified that public benefit is a higher priority for them than financial gain. 
The University Office of Technology Development makes decision whether to protect the IP for the financial benefits of researchers or to waive off for societal benefits. Unless there is any previous agreement made regarding sharing of revenue, $1 / n$th part would be distributed among all the inventors; where $n=$ number of inventors.

Some universities like California University and Columbia University give more importance to patent protection while universities like Harvard and John Hopkins have not been aggressive in the protection of IP on their discoveries and inventions.

\section{IP Policies of HEls' in India}

The Indian higher education network system is the third largest (next to China and the US), and in the near future, it will become the largest education hub in the world. The Council of Scientific and Industrial Research (CSIR), Indian Council of Medical Research (ICMR), and Tata Institute of Fundamental Research (TIFR) are few of the largest networks of premier research institutions in Asia, and the Indian Institutes of Technology (IITs), National Institutes of Technology (NIT), and Indian Institute of Science (IISc) are the technical institutions of national importance, where cuttingedge basic and applied research facilities were provided and produced more patents from India. IIT-Bombay, IIT-Delhi, and IISc were among the few earliest academic institutions that framed IPR policies in India. IIT-Delhi first brought its IPR policy in 1994. The Rajiv Gandhi School of Intellectual Property Law was instituted in IITKharagpur to improve the number of trained lawyers and increase the capacity building in the IP area to serve the needs of industries. Governing and funding bodies of universities and the University Grants Commission (UGC) drafted guidelines for the promotion of awareness and management of IP at universities. ICMR and CSIR have framed their IP policies emphasizing on the commercialization of publicly funded research. The National Research Development Corporation (NRDC) plays a major role in the management of IP from national laboratories and universities.

\section{IIT-Bombay}

The IP policy of IIT-B was established in March 2003. The current version of the IP policy was approved on 14 June 2012. The policy vision was specified as 'to be the fountain head of new ideas and of innovators in technology and science', and the mission was 'to create an ambiance in which new ideas, research, and scholarship flourish and from which the leaders and innovators of tomorrow emerge'. It clearly said the institution's determination to enhance innovation and promote innovators and entrepreneurship. This policy applies to all the IIT-B personnel (students, faculty researchers). It has 2 key bodies for the development and promotion of innovation activities in the institute. They are 'Society for Innovation and Entrepreneurship (SINE) and Industrial Research and Consultancy Centre (IRCC)'. The licensing of IP generated by IIT-B is done through IRCC, which also takes responsibility of evaluation, licensing negotiations, and marketing of IP generated and owned by the 
institute. It is also responsible for facilitating $\mathrm{R} \& \mathrm{D}$, incentivizing researchers, providing advanced facilities, changing policies, etc. SINE was established in 2004, with an accommodation capacity of about 15-17 companies for the purpose of business incubating and promoting entrepreneurship. The Institute has followed the linear type of revenue sharing mechanism which is shared among multiple contributors. After successful licensing, revenue is shared among the inventor and institute in 70:30 ratios. Ownership of copyrights vests with the creator/author only. The institution is not claiming rights over it. The Institute prefers non-exclusive licensing, but under few exceptions, exclusive licenses shall be given. As per 2012 IP policy publication, the IP protection cost will be part of the license sharing agreement. If the IP is generated from collaborative or multiple research consortiums, those agreement terms shall be applicable along with the institution's IP policy. If the collaboration agreement does not specify about the IP terms, the institution's (IIT-B) IP policy shall be applicable (2012; Gargate \& Jain, 2013).

\section{Indian Institute of Science, Bangalore}

The Indian Institute of Science (IISc) started managing its IP from 1950. The Institute received its first patent in 1951. Professor Goverdhan Mehta conceptualized an exclusive office for the promotion of IP from the institution. In 2004, an IP cell was incorporated and it was renamed as IPTeL from 2015. From 1972 to 1977, it actively participated in developing local know-hows and technology transfer activities.

The recent revision of the IISc IP policy was made in 2016. It aims to facilitate the protection and commercialization of IP generated from the institution's research activities. It offers scope for wealth generation and promotes research for the betterment of human life. This policy is applicable to all employees, students, and persons engaged in sponsored schemes along with all visiting scientists/professors/personnel. The linear type of the IP revenue sharing mechanism was used, of which the share of inventor and institution is specified as a 60:40 proportion. If it is sponsored research, the sponsor bears the cost of filing of IP and it shall be a joint IP or an absolute institute ownership IP (Buch, 2019; Murthy \& Krishna, 2015; Samaddar, 2008; Samaddar \& Chaudhary, 2008; Srivastava \& Chandra, 2012; Intellectual Property Policy, 2020).

\section{IIT Kanpur}

The IP policy of IIT Kanpur was drafted and approved in January 2005. As per its policy, IP ownership is entitled to the institution, if it is created using IITK funds/ facilities. The policy is applicable to all employees, students, project staff, visitors, and others, such as trainees from other institutes, participating in IITK programs. The policy also clearly mentioned about the logical, conclusion of IPR, if IITK decides not to protect the IP. In such case, IITK shall waive off the ownership rights to the inventors.

Regarding commercialization of the IP, the Institute followed a revenue sharing model (non-linear step-down type) which clearly divides the earning into 3 parts i.e. inventor's share, institute's share, and a separate account meant for the purpose of commercializing and development of further inventions. 


\begin{tabular}{lllll}
\hline Case & Net earnings & Inventor's share & $\begin{array}{l}\text { Institute's share } \\
\text { Service } \\
\text { account/IPR } \\
\text { cell }\end{array}$ \\
\hline $\begin{array}{l}\text { 1. } \\
\text { For the first amount up to INR 100 lakhs }\end{array}$ & $65 \%$ & $25 \%$ & $10 \%$ \\
$\quad \begin{array}{l}\text { For the next amount between INR 100 } \\
\quad \text { lakhs to INR 200 lakhs }\end{array}$ & $45 \%$ & $45 \%$ & $10 \%$ \\
3. For the next amount more than INR 200 & $25 \%$ & $65 \%$ & $10 \%$ \\
\hline
\end{tabular}

The income generated from the IPR cell through technology licensing is allowed to use for the promotion and upgradation of the invention. Unused funds from IPR cell services and technology licensing will be used for IP commercialization and protection.

The institute through the invention disclosure form asks the inventors of IP to disclose the distribution of IP earnings share among the inventors. In the absence of such disclosure, the earnings shall be equally distributed among all the inventors.

In collaboration with the industry partners, the ownership of IP is decided by the institute on a case-by-case basis; the institute signs the agreement beforehand wherein the jurisdiction of the IPRs, right to commercialize the IPRs, cost of filing and maintenance, and co-applicant status are clearly mentioned in the agreement.

On the other hand, the latest Faculty Entrepreneurship Policy approved in 2019 at IITK provides the license of any number of IPRs to the faculty-run company under the umbrella of $10 \%$ equity as a licensing consideration (Faculty Entrepreneurship Policy, 2019; IP Policy, 2019).

\section{IP Policies of HEls in China}

\section{Tsinghua University}

Tsinghua University is one of the top esteemed higher education and research institutions in China. It has a high success rate in technology transfer and commercialization functions among leading Chinese universities. The most recent IP policy of Tsinghua University was implemented on 31 December 2016. It is applicable to all university employees, including faculty and non-faculty researchers, provisionally hired employees, students, post-docs, and visiting scholars. To whomsoever it is applicable, they need to sign a pledge to comply with the policy. The policy mandates all the investigators to disclose all results of their invention to the administrative department first, which would decide whether to apply for a patent. Tsinghua University allots at least $25 \%$ revenue share to the inventor in terms of cash/equity. For cash income obtained from technology transfer, the university and department get $15 \%$, and other contributors who are involved in the ideation, completion, and transformation of the invention would get $70 \%$ share. Until the first 3 years after a patent was granted, the university pays the patent costs, including application fees, examination fees, agency fees, and maintenance fees for which a separate fund is allocated. For equity obtained from investment by the technology, the university and department get $15 \%$ each, and those individual people who have made important contributions to the completion and transformation of the invention would get $70 \%$ share. 


\section{IP Policies of HEls in South Africa}

\section{University of Pretoria}

The University of Pretoria IP policy specifies that the IP created by employees and contract employees belongs to the university and it may decide in certain cases to waive off the ownership to the employee on request in certain cases. Ownership in case of IP generated in joint projects outside the organization shall be based on the agreement made with that organization. Visiting lecturers and scholars must sign a confidentiality agreement before their visit saying that IP generation in their visit will get assigned to the university. Generated intellectual property may be on university decision upon intimation with the involved inventors, maybe a spin-off into a separate entity, and it would be the part of Enterprise at University of Pretoria ( $E$ at UP). University, inventors, and other involved shall be the shareholders, and it would be a wholly owned subsidiary of E at UP. The university TTO puts a separate account for each IP product. Revenue distribution on commercialization is done in 4 components. The first two components deal with the recovery of direct (university surcharge) and indirect expense (legal expenses) recovery which would be $10 \%$ of gross income to the university, and direct expenses would be recovered from concerned parties involved in gross sharing and the next two components relate to net revenue division the first R400,000 of net income that is distributed among the inventor, university research account, and staff involved in the proportions of $50 \%$, $50 \%$, and $25 \%$, respectively. And the remainder of the net income after the first $\mathrm{R} 400,000$ is distributed among the same as abovementioned in the proportions of $35 \%, 15 \%$, and $20 \%$ respectively and $30 \%$ to the University of Pretoria's Intellectual Property Leverage Fund (2018).

Ownership and revenue sharing mechanisms of HEIs are given in Table 1.

\section{Impact of National IPR Policies and HEls' (Universities and Research Laboratories) IP Policies on IP Generation}

Because of the substantial changes it brought in the patent procedures and the success it has seen, the US IPR policy evolving process can be seen as 'policy before 1980' and 'policy after 1980'.

\section{IP Policy of USA before Bayh-Dole Act (BDA) 1980}

Before 1980, there were no concrete national-level IP policies and universities involved in innovative activities. The Land-Grant Act signed by Abraham Lincoln was the first major boost during that period in establishing universities which are top-performing institutions now. Until 1975, universities did not prefer direct involvement in patent management. Instead, they had an indefinite contract with non-profit, independent foundations that act as patent management agents for all patentable 


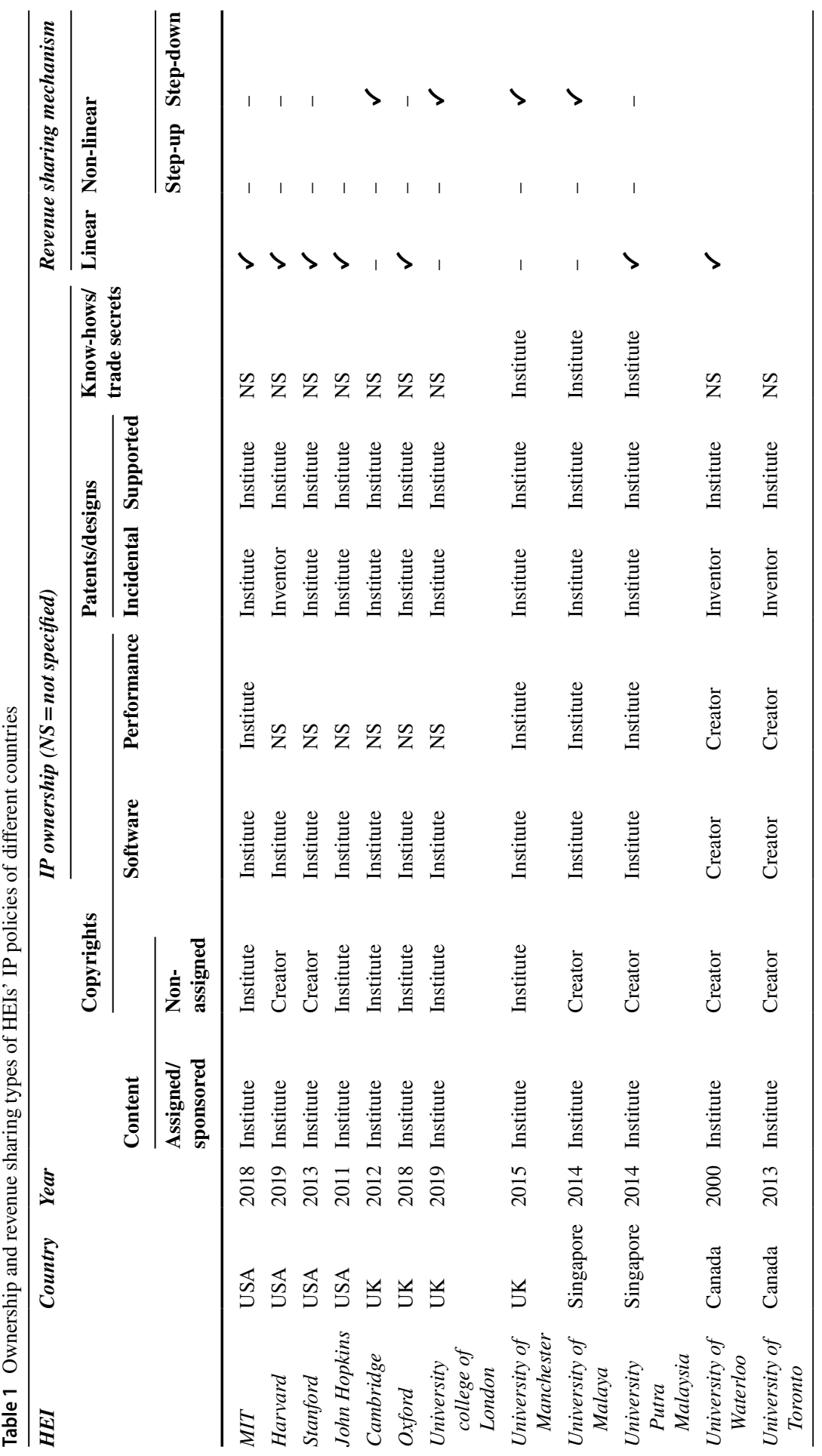




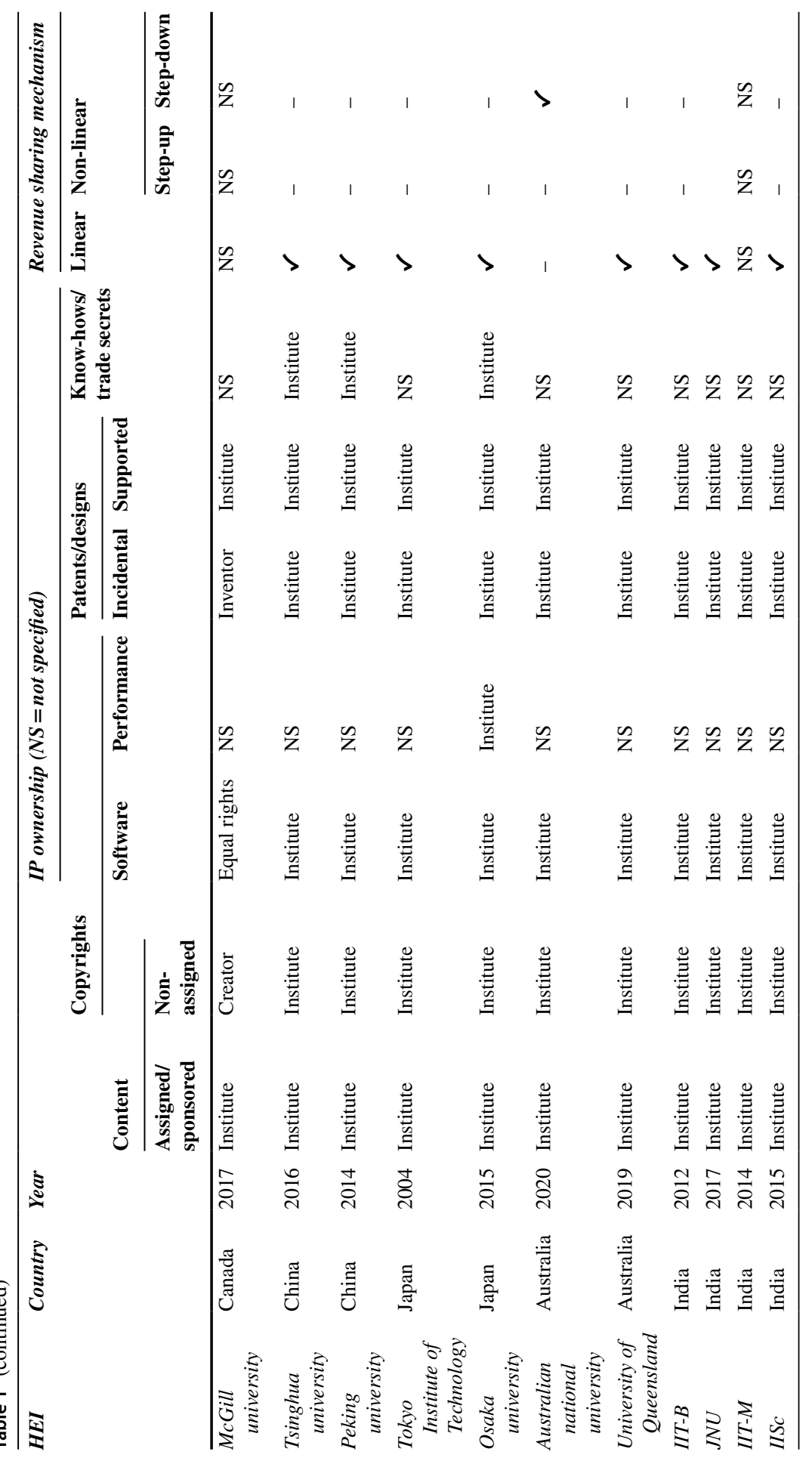


inventions and discoveries. They made agreements with individual inventors for their inventions and also for the entire university as per their requirements. Universities are reluctant and passive to be involved in litigations and infringement suits. These independent patent management contractors take the call on litigations and legal issues as universities and national laboratories do not have expertise in handling those issues and apprehend that it would affect their relationship with investors, funders of the research, and commercialization channels. 'Research corporations' was one among such non-profit foundations that had contractual agreements for managing patents with 39 Land-Grant universities during 1945. The prominent universities established under this are Cornell, Maryland, Michigan State, MIT, Ohio State, Penn State, Rutgers, Texas A\&M, West Virginia University, Wisconsin, and the University of California. A National Patent Planning Commission, ad-hoc body was established in 1945, to examine the patents developed during the war. Over 30 years, there was uncertainty regarding the entitlement and exclusive rights of federally funded research innovations until the enactment of BDA. In 1950, congress allocated $\$ 15$ million to establish NSF to support basic scientific research at universities.

During the 1970s, the scenario changed and for the first time, private universities started getting involved directly in the management of their intellectual property. MIT and Wisconsin universities are first among Land-Grant universities, which started collaborating with industries. Studies showed a growth of biomedical patents by universities when it took a direct involvement in the management of IP. Public universities were more heavily represented in patenting than private ones in that period. Due to an economic slowdown, the US patent system was weak and ineffective at the end of the 1970s. USPTO was overworked and understaffed. In fast-moving technological fields, inventions were found to be getting obsolete by the time of PTO granting the patents.

President Nixon in 1971 started a patent policy to promote the commercialization of federal inventions for the benefit of the private sector and to put economic growth on track. In the year 1975, the government had about 28,000 patented inventions but less than $5 \%$ of them were in practice to business.

\section{IP Policy Changes in the USA After 1980}

The economic slowdown of the USA during the 1970s made the federal government initiate a few policy changes to bring it on track. Out of those, the Bayh-Dole Act (BDA) of 1980, the Stevenson-Wydler Act of 1980, the Small Business Innovation and Development Act of 1982, and the National Cooperative Research Act of 1984 are prominent which brought policy changes to technology and innovation in universities, public research laboratories, national laboratories, and small business entities. There were many arguments from policymakers and advocates regarding ownership and exclusive rights for federally funded $R \& D$ innovations. Few argued for a government entitlement of the public-funded research results for the wider diffusion of the innovation, and few arguments were for policy supporting patent entitlement to contractors and allowing exclusive licenses to them. The government was uncertain between these views before World War 2 . 
Jaffe et al. categorized the policy objectives of the Bayh-Dole Act and policy changes after it into 4 groups. They are (1) establishment of new courts to review patent decisions, (2) special privileges to researchers and contractors who create commercially viable inventions, (3) broadening of patentability subject criteria for new technology areas, and (4) harmonization of patent protection across the world.

\section{Impact of IP Policy Reforms in National Laboratories in the USA}

Land-Grant universities were the first group of universities that started managing faculty-generated IP before the enactment of BDA. Wisconsin University and MIT were among them. The BDA and Stevenson-Wydler Act policies influenced a lot in the promotion of the generation of IP and commercialization in universities and the national laboratories. Before the enactment of the Stevenson-Wydler Act, technology transfer was not facilitated at national laboratories. This Act mandated the establishment of Office of Research and Technology to disseminate federally funded research output, having potential applications to state, local government, and private industry (Link et al., 2011). Using the patent citation method, Jaffe et al. studied the impact of 1980 patent policies on patenting activity using patent citation data of two Department of Energy (DOE) laboratories, the Lawrence Livermore National Laboratory (LLNL) and the Idaho National Engineering and Environmental Laboratory (INEEL). In both the DOE laboratories and NASA, he found an increase in patenting without any change in quality of patents. He also found dramatic and positive effects of increase in the commercialization activity due to the policy reforms of 1980 (Jaffe \& Lerner, 2001).

LLNL was established in 1952, specialized in nuclear weapons research operated by University of California. Even before the enactment of BDA, it has strong relationships with computer and laser industries in Livermore. Relationships with the industries and vendors were informal, and LLNL neither seek to patent their inventions nor claimed for holding the patent ownership before 1980. Laboratory contractors were assigned few patents, and exclusive licenses are rare. After the 1982 implementation of the Stevenson-Wydler Act, there was initially limited funding and a formal technology transfer office was established. After the passage of the National Competitiveness Technology Transfer Act of 1989, DOE increased funding to CRADAs (Cooperative R\&D arrangements) which improved the number of projects. Lack of exclusive licenses and issues of conflict of interest caused a lower number of commercialized patents generated before 1980. IP policy and management-related impediments were clearly seen as reasons for the decrease in the commercialization of Public Research Institutions' inventions before IP policy reforms (Jaffe, 2000; Mowery \& Ziedonis, 2001).

\section{Policies of the US Universities Before 1980}

IP policies of US institutions before 1980 can be seen as 3 types: institutions that had serious concern over IP matters (formal IP policies), laissez faire attitude institutions (who followed general practises with verbatim policies), and institutions that did not have IP policies. 


\section{Institutions with Formal IP Policies}

Most of the universities first started managing IP with formal IP policies. They had policy framed for every specified instance to handle sponsored/contract research. They also had in-house non-profit research foundations to look after IP-related issues with dedicated IP staff. They had indefinite contracts with external non-profit independent patent agent corporations like research corporations to manage the IP. Inventors, on requesting to university, could take the ownership of IP and collaborate with research corporations for IP management. In the absence of such policy, it was carried out based on mutual agreements. Determination of licensing and sharing of benefits was on an ad-hoc basis. About 70 institutions were having formalized policies before 1980 .

\section{Institutions with Informal IP Policies}

Only for the sake of contract/sponsored research activities did some institutions make verbatim IP practices with general rules. They were not directly involved in legal matters; instead, they completely relied on research corporations or any such independent contractor IP management.

\section{Institutions Without IP Policies}

Laissez faire attitude was seen in these institutions. Inventors were allowed to take their own decisions on their invention without any formal/informal policies (Palmer, 1952).

\section{Impact of IP Policy Reforms on Universities in the USA}

Before 1980, IP management and ownership were given to research contractors. The number of invention disclosures and patent filings was very low. After the passage of IP policies, patenting was dramatically increased in those institutions which had formal IP policies and previous patenting experience.

\section{Impact of HEls' IP Policies on Innovation Output}

Since 1980, a 5\% increase in average patent applications and grants was observed than in the previous century (Hu \& Jaffe, 2007). The key objectives of post-1980 patent policies in the USA were (i) entitlement of patents generated from publicfunded research results, (ii) incentives for licensing and technology transfer of inventions to small businesses, and (iii) increasing the probability of winning the patent cases through establishments of CAFC (Court of Appeals for Federal Circuits).

To a certain extent, these parameters of major patent policy reforms were the reason for this increase in the rate of inventions and patents were studied and evaluated by various scientists in different methods. Proponent and opponent views regarding 
the magnitude and direction of the policy impact on promulgating the science and technology output from HEIs are discussed in the following.

The effect of policy changes on the commercialization of publicly funded research was studied by Josh Lerner and Adam B. Jaffe using patent citation analysis. They found that policy caused dramatic and positive effects on technology commercialization. Patenting number increased, but the quality of patents has been reduced in labs. In universities, the overall increase in patents does not seem to have affected the quality of patents. Monetary and non-monetary awards and types of formal and informal reward schemes at labs and universities caused this change.

Post-Bayh-Dole Act, new university entrants into academic patenting received fewer quality patents compared to the incumbents who have experience in patenting before the Bayh-Dole Act. Mowery et al. found in their study that after 6 years of BDA legislation, biomedical patenting required less patenting experience than nonbiomedical patents and incumbent universities had more advantages towards nonbiomedical patenting than biomedical fields. Institutions who were previous clients to Research Corporations were successful in attaining biomedical patents than nonbiomedical patents (Mowery et al., 2002).

Incentives provided through BDA are successful in increasing the rate of patenting and extent of licensing, which increased tremendously from universities. However, BDA and any other corresponding policy changes have not significantly changed the generation of the rate of commercially important inventions at universities. It might be due to the following: either universities did not shift the areas of research to produce commercial inventions or even if they tried, they failed in it (Takahashi \& Carraz, 2011).

\section{Discussion}

The key elements of the innovation system lie in universities, research institutions, technological institutions, and national laboratories which are knowledge bases in the innovation system. Innovation policy helps in the regulation and management of elements of the innovation system which includes the framework conditions, legislations, internal organization of universities, and how they link to industries. At the knowledge bases of the country, the science policy of the nation regulates and promotes the generation and flow of information. Technology policy helps in commercialization of knowledge and technology, knowledge and information flow from institutions to enterprises, and commercialization of knowledge and technology from lab to market involved in the exchange of intellectual property which needs to be controlled, regulated, and protected through policies. A robust Intellectual Property Rights policy at the central level and supporting IP policy to it at the HEI level can only guide these entire processes of generation, protection, and management of IP.

National and HEI IP policies have a prominent role in promoting the country's innovation and thereby increasing the national economy. The comparison of key components of both of these IP policies and their framework in different countries and how it influenced the innovation and economic output are discussed below. 
Whatever the innovation model they had implemented, when IP policy reforms were made at a national level in a top-down nature, it improved the country's economy significantly in the USA and other developed nations. In Japan, after 'Basic law' enactment and establishment of the national IP strategy, professorial patenting with firms fell significantly, while university-entitled patents increased, and there was no change in quantity of university patenting. Studies show that TLO (Technology Licensing Office) mediation in the technology transfer process did not change the output quantity of IP and commercialization. According to the Ministry of Economy, Trade, and Industry (METI), the spin-offs from universities after basic law enactment and its directive IP strategies have positively impacted Japan's economy by creating jobs and introducing new products and services (Tantiyaswasdikul, 2013). Though Sweden and USA follow contradictory models of innovation, both are successful in promoting innovation in their countries. Some studies showed that the rate of commercialization of academic research results was less in Sweden compared to USA (Cantù et al., 2015). In Canada, the Federal government does not have top-down higher education policy. The curriculum and administration of HEIs operate independently. Commercialization of research in Canadian HEIs was influenced by several other factors like cultural orientations within HEIs, their IPR policies, and the structure of the Canadian economy which largely consists of SMEs (small and medium-sized enterprises). The content and administration of IP policies vary a lot across different universities. Few universities follow inventor ownership, and few others have university ownership models. Because of the lack of strong top-down policies and the presence of more regionally based policies, the University of Waterloo became an exemplary for other HEIs. To make HEIs as entrepreneurial entities, the government made several modifications in their funding strategy, based on the collaboration status of HEIs with prominent funds from industries. China became the top filers of IP in the world. HEIs' contribution to that achievement is significant because of the two amendments to the Patent Law: the first amendment in 1993, which granted the Public Research Institutions the legal right to own the IP generated by their research, and the second in the year 2000, which gave entitlement of IP rights of their research through contracts or agreements with their PRIs (Bramwell \& Wolfe, 2008; Gabriel, 2007).

The key elements of the innovation system lie in universities and research institutions, which are knowledge bases in the innovation system. It includes the organizational arrangements, process of universities, and their linkages with industries. At the institutional level, the science policy of the nation regulates and promotes the generation and flow of information. Knowledge and information flow from institutions to enterprises involves the exchange of tacit information which needs to be controlled, regulated, and proceeded through policies. The intellectual property rights policy at the central and institution levels should guide these entire processes of managing and protecting of IP from the knowledge bases to industries.

The prime objective of Intellectual Property Rights is to commercialize the R\&D output for the benefit of society and improve the regional and national economy by providing royalty and exclusivity. It provides the innovator a token of incentive to continue the spirit of innovation. Commercialization is the key motto of the patent system of any country. The same was explicitly specified in Section 146 (2) of the 
Indian Patent Act (1970). It says about the power of controller to call for the inventor at any time and to provide information in writing within 2 months of notice, about working of the patent, or to what extent it commercially worked (Trimble, 2016). A similar clause was stated in the USA code as well. However, a weak IP policy framework and inadequacy of incentive structures in HEIs are not allowing their innovations for IP generation and commercialization. It is clearly observed that, in the early stages of development, the country's R\&D potential is weak, and it is needed to have a balanced IP policy supporting local benefits and the development of indigenous innovations.

In the USA, there was a period when foreign patent applications were not allowed, if they get, that would be very difficult and of less chance (Hu \& Jaffe, 2007). In the beginning of the nineteenth century, the USA was a frequent infringer of foreign IPR, until their copyrights Act was amended (Furukawa, 2010). Their IPR policy supported the use of foreign IPR for the benefit of the country until their level of innovation skills was improved. Many studies reported that the IPR protection and innovation are correlated in an inverted ' $U$ ' shape. In the early stages of countries' development, protection of IPR is weaker until they attain self-sufficiency in making innovations (Gangopadhyay \& Mondal, 2012; Lerner, 2002). Lerner et al. studied changes in patent law over 150 years in various countries for understanding the correlation of the number of patents with changes in the law. Under strong IPR protection, foreign IPR filings were more, while it did not affect the national patent applicants (Hu \& Jefferson, 2009). Many developed countries followed a stronger IPR protection policy when they framed policies but were later forced to weaken their protection system during 1960-1970. The IPR policy of China regarding utility patents and the continuation of weak strength of protection of IPR are so crucial, which resulted in tremendous innovation growth (Gabriel, 2007; Hu \& Jefferson, 2009). The Indian IP policy of 2016 was also given weak protection to western countries' IPR, mainly in the pharmaceutical patent sector by utilizing the flexibilities under the TRIPS agreement. But it did not explicitly mention what strategies they do bring to offset and balance the benefits of the society. Stronger protection of IPR impedes knowledge dissemination and information flow from universities to society (Huang, 2006).

The Bayh-Dole Act, an amendment to the Patent and Trademark Act, tremendously influenced other countries to take a similar approach. The policy reforms during 1980 were believed to be successful in attaining the objectives of the Act. Closer linkages among universities and industries encouraged an increase in technology transfer activities and promoted innovation leading to the market. On another side of it, there were some issues pointed on decreasing openness in scientific discovery, decreased emphasis to basic research, and inaccessibility of benefits of pharmaceutical and biotechnical research outputs to society. Many opined that privatization of academic research is a threat to the university's nature of openness of science (Sampat, 2006).

IP policies are not yet made in most of the HEIs, and in those HEIs where IP policies were implemented, their consistency regarding ownership and incentives is not sufficient in defining them as per the needs, and they are not so clear about the confidentiality and protection of the IP they generated. During 1958-1980, most of 
the institutions in USA framed their IP policies. Declaration forms, due diligence statements, and payout frequencies of net revenue generated from IP commercialization are not much in practice in Indian HEIs. Rules relating to assigning the rights of ownership to institute or transfer of rights to third parties during the sponsored research and commercialization are or not specified except in a few top HEIs' IP policies like IISc and IITs. In fact, many universities have R\&D strategies but not specifically for Intellectual Property policy. How far the researcher/staff are aware of the implemented IP policy and to what extent the enforcement of IP right stated by the HEI IP policy is reliable and successful in protecting are not evaluated.

The actual contributor to the innovation/inventor(s) is left behind without receiving any benefits from intellectual output. Lack of giving importance and incentives to the inventor might be the major drawback in HEIs' IP policies in India. By observing IP policies in different institutions across India, only few IITs have a policy to share a percentage of revenue to the inventor(s) from successful commercialization. Majority of HEIs have not specified its royalty sharing mechanism or ownership of the IP generated. And it is also so clear that universities of the USA have mentioned their formula and deductions that are intended to make in royalty distribution for faculty of department, university centre, and respective licensing offices in those universities. This is not observed in most of the Indian HEI policies. Indian HEIs do not follow the inventor ownership model of IP entitlement which is mostly seen in European nations. Similar to the Bayh-Dole Act, the "Protection and Utilization of Public Funded Intellectual Property Right" (PUPFIR) bill was introduced in 2008, but the standing committee has withdrawn it in 2014, suggesting that there should be more transparency in public-funded intellectual property and it is more beneficial to the industry with little or no advantage to the general public in utilizing the returns of innovation output from public-funded R\&D.

The TRIPS agreement was made in 1995, and it gave all signatory countries a period of 10 years to make their respective national laws in line with the agreement rules. We can say that India has successfully met that timeline for making it compliant, but it is clear that it did not productively use the strength of HEIs in building the country's economy. In a way, India has failed in inculcating an entrepreneurial mindset and bringing awareness among researchers and staff in universities in generating IP though it has great human capital and well-established institutions. HEIs' role in building sustainable knowledge-based economies has been proved in many countries, and it is not yet fully tapped to stimulate and inculcate an innovation-making mindset in Indian universities. The MHRD (Ministry of Human Resource and Development) initiative NIRF (National Institute of Ranking Framework) started giving rankings to the universities based on their performances in various aspects including generation and licensing of intellectual property by them. This has brought a substantial change in making institutional IP policies and building an innovation ecosystem including incubation centres with the help of government funds. But it is still not sufficient to compete enough with countries like USA and China, whose technological advancements are in fast-forward motion. The need for identifying Intellectual Property as a separate policy area is of high time now. In some countries, the IPR policy of the nation is integrated with the innovation policy or R\&D policies and made part of their national development program which is not seen in 
all countries. Imitating national IPR policies of developed nations is not always successful in developing and least developed countries. National IPR policies, strategies, and goals are entirely dependent on their National Innovation System of that country. The universal adoption of the USA like policies hurts developing countries for the benefit of the rich countries (2018). Development of national policies should address national issues and reflect their regional and national benefits.

\section{Conclusion}

In most developed nations, there is no consolidated national IPR policy formulated yet. Though USA has a national IPR strategy prioritizing Science, Technology, Engineering and Mathematics education (STEM), it did not formulate a consolidated national IPR policy. HEIs in the USA have institutional IP policies since 1980. The early adoption of the IP policy in HEIs helped them in the generation of high-quality IPs which created value by its commercialization and technology transfer. The Japan national IPR policy is well formulated, stating current issues, goals, and strategies to achieve specified goals. The basic law enacted by Japan brought significant changes in technology commercialization from universities by establishing many technology licensing offices. With the help of WIPO, South Africa, Sri Lanka, and Bangladesh have formulated national IPR policies supporting HEIs' innovations.

Despite having enormous potential of intellectual capital and infrastructure with which it can lead the world in technology, India is not effectively utilizing its HEIs to strengthen its innovation ecosystem and to contribute in the national economy. In fact, it was too late for the Indian government to set a national-level IPR policy in 2016, to promote IP awareness and strengthen the IP in research institutions and universities. It can be considered as a landmark step for fostering IP-based economies in India. However, there are some objections pointed in the policy framework, as it did not specify how it balances community interests and private needs with recommended stronger IP protection. Many advocates and stakeholders pointed out that policy objectives are not evidence-based and do not suit for industrial developments anticipated. However, the recent policy initiation from the government made a positive change in the HEIs' innovation system. Many HEIs formulated their IP policies, established IP cells, and raised awareness among researchers. The quality of patents emanating from universities and research institutions is still low, and the same is a major barrier for commercialization and technology transfer activities. To mitigate this barrier, IP policy of HEIs need to be formulated in a way it enables and motivates industries to collaborate for $\mathrm{R} \& \mathrm{D}$ activities.

Adopting national IPR policy objectives into the state government's IP strategies and HEI policies at the regional level and coordinating the stakeholders involved in innovation remained a challenging task. Adopting mission-oriented responsible research projects and instituting specialized incentives for inventors as policy tools are required for supporting universities and research institutions for industry linkages. Technologyspecific or sector-specific IP policy may be helpful in balancing the international free trade with developed countries and meeting the needs of society. 
Acknowledgements The authors are thankful to the Department of Science and Technology (DST), NSTMIS, CHORD Division, Government of India, and Manipal Academy of Higher Education (MAHE), Manipal, for providing library resources.

Funding Open access funding provided by Manipal Academy of Higher Education, Manipal.

Open Access This article is licensed under a Creative Commons Attribution 4.0 International License, which permits use, sharing, adaptation, distribution and reproduction in any medium or format, as long as you give appropriate credit to the original author(s) and the source, provide a link to the Creative Commons licence, and indicate if changes were made. The images or other third party material in this article are included in the article's Creative Commons licence, unless indicated otherwise in a credit line to the material. If material is not included in the article's Creative Commons licence and your intended use is not permitted by statutory regulation or exceeds the permitted use, you will need to obtain permission directly from the copyright holder. To view a copy of this licence, visit http://creativecommons.org/ licenses/by/4.0/.

\section{References}

Basheer, S, \& Agarwal P. (2017). India's new IP policy: A bare act. The Indian Journal of Law and Technology, 13(2).

Bramwell, A., \& Wolfe, D. A. (2008). Universities and regional economic development: The entrepreneurial University of Waterloo. Research Policy, 37(8), 1175-1187.

Brandl, K., Darendeli, I., \& Mudambi, R. (2019). Foreign actors and intellectual property protection regulations in developing countries. Journal of International Business Studies, 50(5), 826-846.

Buch, N. (2019). Concept to commercialization: Decoding the IP strategy for academia. Asian Journal of Research in Social Sciences and Humanities, 9(5), 1-12.

Cantù, C., Corsaro, D., Tunisini, A., de Zubielqui, G. C., Jones, J., Seet, P. S., \& Lindsay, N. (2015). Knowledge transfer between actors in the innovation system: A study of higher education institutions (HEIS) and SMES. Journal of Business \& Industrial Marketing.

Carayannis, E. G., Grigoroudis, E., Campbell, D. F., Meissner, D., \& Stamati, D. (2018). Mode 3 universities and academic firms: Thinking beyond the box trans-disciplinarity and nonlinear innovation dynamics within coopetitive entrepreneurial ecosystems. International Journal of Technology Management, 77(1-3), 145-185.

Deere Birkbeck, C. (2009). The politics of intellectual property reform in developing countries. intellectual property and sustainable development: development agendas in a changing world, pedro roffe, ed., Edward Elgar press: Oxford.

Du Plessis, M. (2007). The role of knowledge management in innovation. Journal of Knowledge Management.

Edquist, C. (1997). Systems of innovation: Technologies, institutions, and organizations. Psychology Press.

Faculty Entrepreneurship Policy. (2019). from https://siicincubator.com/wp-content/uploads/2019/02/ Faculty-Entrepreneurship-Policy.pdf

Foxon, T., Makuch, Z., Mata, M., \& Pearson, P. (2004). Innovation systems and policy-making processes for the transition to sustainability. Governance for Industrial Transformation: Proceedings of the 2003 Berlin Conference on the Human Dimensions of Global Environmental Change. Environmental Policy Research Centre, Berlin.

Furukawa, Y. (2010). Intellectual property protection and innovation: An inverted-U relationship. Economics Letters, 109(2), 99-101.

Gabriel, R. M. (2007). The patent revolution: Proposed reforms in Chinese intellectual property law, policy, and practice are the latest step to bolster patent protection in China. APLPJ, 9, 323.

Gangopadhyay, K., \& Mondal, D. (2012). Does stronger protection of intellectual property stimulate innovation? Economics Letters, 116(1), 80-82.

Gargate, G., \& Jain, K. (2013). Role of IP Policy in innovation and entrepreneurship development: Case study of HEI in India. Udyog Pragati, 37(3), 19-29. 
Ghosh, P., Kashyap, A., \& Agrawal, R. (2016). Mapping the position of higher educational institutes in national economic advancement: A comparative analysis. International Journal of Technological Learning, Innovation and Development, 8(3), 283-302.

Godin, B. (2009). National innovation system: The system approach in historical perspective. Science, Technology, \& Human Values, 34(4), 476-501.

Gopalakrishnan, S., \& Santoro, M. D. (2004). Distinguishing between knowledge transfer and technology transfer activities: The role of key organizational factors. IEEE Transactions on Engineering Management, 51(1), 57-69.

Hu, A. G., \& Jaffe, A. B. (2007). IPR, innovation, economic growth and development. Department of Economics, National University of Singapore.

Hu, A. G., \& Jefferson, G. H. (2009). A great wall of patents: What is behind China's recent patent explosion? Journal of Development Economics, 90(1), 57-68.

Huang, K. G. L. (2006). Innovation in the life sciences: The impact of intellectual property rights on scientific knowledge diffusion, accumulation and utilization, Citeseer.

Intellectual Property Policy. (2020). Retrieved December 15, 2020, from https://www.iisc.ac.in/wp-content/ uploads/2016/06/Intellectual-Property.pdf

IP Policy. (2019). Retrieved December 15, 2020, from https://siicincubator.com/wp-content/uploads/ 2019/10/IPR-Policy_IIT-Kanpur.pdf

IP Policy. (2012). Retrieved May 5, 2020, from https://rnd.iitb.ac.in/ip-policy

Jaffe, A. B. (2000). The US patent system in transition: Policy innovation and the innovation process. Research Policy, 29(4-5), 531-557.

Jaffe, A. B., \& Lerner, J. (2001). Reinventing public R\&D: Patent policy and the commercialization of national laboratory technologies. RAND Journal of Economics, 167-198.

Kashyap, A., \& Agrawal R. (2019). Academia a new knowledge supplier to the industry! Uncovering barriers in the process. Journal of Advances in Management Research.

Keller, W. (2010). International trade, foreign direct investment, and technology spillovers. Handbook of the Economics of Innovation, Elsevier., 2, 793-829.

Lerner, J. (2002). 150 years of patent protection. American Economic Review, 92(2), 221-225.

Link, A. N., Siegel, D. S., \& Van Fleet, D. D. (2011). Public science and public innovation: Assessing the relationship between patenting at US National Laboratories and the Bayh-Dole Act. Research Policy, 40(8), 1094-1099.

Lundvall, B. A., \& Borrás, S. (2005). Science, technology and innovation policy. The Oxford Handbook of Innovation, 599-631.

Lundvall, B. A. (2007). National innovation systems-Analytical concept and development tool. Industry and Innovation, 14(1), 95-119.

Martin, R., \& Sunley, P. (2006). Path dependence and regional economic evolution. Journal of Economic Geography, 6(4), 395-437.

Meyer, M. (2002). Tracing knowledge flows in innovation systems. Scientometrics, 54(2), 193-212.

Model guidelines on implementation of IPR Policy for academic institutions. (2019). D. f. P. o. I. a. I. Trade, CIPAM.

Mowery, D. C., Sampat, B. N., \& Ziedonis, A. A. (2002). Learning to patent: Institutional experience, learning, and the characteristics of US university patents after the Bayh-Dole Act, 1981-1992. Management Science, 48(1), 73-89.

Mowery, D. C., \& Ziedonis, A. A. (2001). The commercialisation of national laboratory technology through the formation of" spin-off" firms: Evidence from Lawrence Livermore National Laboratory. International Journal of Manufacturing Technology and Management, 3(1-2), 106-119.

Murthy, H., \& Krishna, G. (2015). How IISc can contribute to society? Current Science, 109(11), 1909.

Nakayama, S., \& Low, M. F. (1997). The research function of universities in Japan. Higher Education, 34(2), 245-258.

National Intellectual IPR Policy. (2016). National Intellectual IPR policy. Department of Industrial Policy and Promotion, Government of India.

National Innovation and Intellectual Property Policy. (2018). Ministry of Industries. Bangladesh, Government of People's Republic of Bangladesh.

Palmer, A. M. (1952). University patent policies and practices, National Academies.

Payumo, J., Gang, Z., Pulumbarit, E., Jones, K., Maredia, K., \& Grimes, H. (2012). Managing intellectual property and technology commercialization: Comparison and analysis of practices, success stories and lessons learned from public research universities in developing Asia. Innovation, 14(4), 478-494. 
Rasmussen, E., Moen, Ø., \& Gulbrandsen, M. (2006). Initiatives to promote commercialization of university knowledge. Technovation, 26(4), 518-533.

Ray, A. S., \& Bhaduri, S. (2008). Co-evolution of IPR policy and technological learning in developing countries: A game-theoretic model. Georgia Institute of Technology.

Reichman, J. H. (2009). Intellectual property in the twenty-first century: Will the developing countries lead or follow? Houston Law Review/university of Houston, 46(4), 1115.

Samaddar, S. G. (2008). Governance of intellectual property strategy for a technical institute: Effective policy formulation.

Samaddar, S. G., \& Chaudhary, B. D. (2008). Practical insights into intellectual property strategy for a technical institute.

Sampat, B. N. (2006). Patenting and US academic research in the 20th century: The world before and after Bayh-Dole. Research Policy, 35(6), 772-789.

Section 146 of the Indian patents Act. (1970). I. India: 100-101.

Srivastava, P., \& Chandra, S. (2012). Technology commercialization: Indian University perspective. Journal of Technology Management \& Innovation, 7(4), 121-131.

Takahashi, M., \& Carraz, R. (2011). Academic patenting in Japan: Illustration from a leading Japanese university (pp. 86-107). Academic Entrepreneurship in Asia. Edward Elgar Publishing.

Tantiyaswasdikul, K. (2013). Intellectual property rights policy and university technology transfer output in Canadian universities. Review of Integrative Business and Economics Research, 2(2), 467.

Trimble, M. (2016). Patent working requirements: Historical and comparative perspectives. UC Irvine Law Review, 6, 483.

University of Pretoria Intellectual Property Policy. (2018). from https://www.up.ac.za/media/shared/538/ ZP_Files/up-ip-policynipmo.zp68489.pdf

Publisher's Note Springer Nature remains neutral with regard to jurisdictional claims in published maps and institutional affiliations.

\section{Authors and Affiliations}

\section{Vijay Sattiraju ${ }^{1} \cdot$ Virendra S. Ligade $^{1} \cdot$ Pradeep Muragundi $^{1} \cdot$ Ravi Pandey $^{2}$. Manthan D. Janodia ${ }^{1}$}

Manthan D. Janodia

manthan.j@manipal.edu

1 Department of Pharmacy Management, Manipal College of Pharmaceutical Sciences, Manipal Academy of Higher Education, Manipal, Karnataka 576104, India

2 Start-Up Innovation and Incubation Centre, Indian Institute of Technology Kanpur, Kanpur, UP 208016, India 